\title{
Study on Reform of College English Stratified Teaching Based on School-based Characteristics
}

\author{
Liu Yang \\ English Department, College of Literature and Law, Sichuan Agricultural University \\ Ya'an 625014, Sichuan, China \\ E-mail: Lydia2000@yeah.net
}

Received: January 23, 2012

Accepted: January 31, 2012

Published: May 1, 2012

doi:10.5539/elt.v5n5p62

URL: http://dx.doi.org/10.5539/elt.v5n5p62

Foundation Item: Part of Research Achievements in Sichuan Agricultural University' Talents Cultivation Quality and Teaching Reform "Establishment of the New System in College English Teaching Based on School-based Characteristics" in 2011, Foundation NO: X2011029.

\begin{abstract}
Considering the status quo of college English teaching, we implement stratified teaching, which reflects the idea of stratification in terms of teaching objects, teaching management, teaching process and assessment and evaluation, makes each students get development to the greatest extent in interactive teaching practice of teaching and learning and facilitates students' cultivation and improvement of practical competence in English usage. Stratified teaching should be consistent with positioning of the school and the goal and requirement of talent cultivation and satisfy requirements of individualized teaching at the time of reflecting characteristics of agricultural and forestry schools and subjects.
\end{abstract}

Keywords: School-based characteristics, College English, Stratified teaching

\section{Introduction}

Whether from the perspective of national development or from the perspective of personal need, the importance of college English teaching should never be neglected. College English course is a public and basic required course that serves non-English undergraduate majors in institutions of higher learning and is an organic component of the holistic education in universities. It is closely connected with cultivation and development of students' professional skills, comprehensive quality, humanistic quality and innovation capacity. In the past few years, with the change of higher education from "elite" to "universalness", the structure of students sources has also taken a great change. Especially, for some higher agricultural universities, the scale of running a school is expanded, the level of running a school increases and the varieties of majors and subjects increased and students from all over the country have uneven English foundation. If we continue to organize the teaching of English courses according to the traditional classroom teaching system that is classified based on majors and adopt the same teaching goal, the same teaching syllabus, the same teaching materials, the same teaching means and the same assessment and evaluation standard, namely, a teaching model of "one size fits all", then it is necessary to cause the polarization phenomenon that "top students are on short commons" and "underachievers can't finish all", which may affect students' enthusiasm in learning and impede cultivation and improvement of students' competence of practical English usage. Obviously, this does not conform to the goal of college English teaching. It is a significant issue faced up by the reform in college English teaching at the present stage how to keep the industrial and subject characteristics and advantages in a new situation, improve the college English teaching system and enhance the holistic teaching level. Wang Shouren (2011) and Shu Dingfang (2006) et al discussed and made clear the mission and task in college English teaching; Zhou Yongmo (2011) et al analyzed the status quo of English teaching in agricultural and forestry college English teaching and the coping strategies; Chen Linxia (2005) and Zhao Liang (2011) et al made an in-depth analysis of the importance and feasibility of stratified teaching in college English. Thus, with ongoing of education reform, implementation of stratified teaching is a necessary requirement of college English teaching at a new period and is also an important component of the current implementation of reform in college English teaching that is led by listening and speaking. And with stratified teaching as a breakthrough, we can set up a complete, scientific and standard stratified teaching system for basic and subsequent college English courses. Stratified teaching should be 
consistent with positioning of the school and the goal and the requirement of talent cultivation and satisfy requirements of individualized teaching at the time of reflecting characteristics of agricultural and forestry schools and subjects, so as to enable teaching of college English to serve for the target of running a school, serve for the colleges and departments, serve for students and enable students to obtain self development in the development of their schools and finish their mission and task excellently.

\section{Importance and Necessity of Stratified Teaching}

"Requirements for College English Course Teaching" [2007] NO.3 by the Higher Education Department of Ministry of Education proposed three requirements, namely, "general requirement", "high requirement" and "higher requirement". "General requirement" is the lowest English standard of university students, and "high requirement" is aimed for students who have better English basis and need to further improve their English level. "Higher requirement" requires students to be able to have fluent social intercourse and cultural and academic exchange in English through their learning of English at the stage of university. According to these requirements, students of different majors at different levels should acquire perfect interpersonal means and methods and learning tactics at the time of obtaining English knowledge and culture through their learning of college English so as to satisfy their personal English requirements and improve their learning effects. Stratified teaching of college English is to classify students into different levels in an accurate and appropriate way, determine different levels of teaching goals, work out different teaching plans, employ different teaching methods, carry out different forms of tutoring, and organize different forms and standards of assessment according to the principle of improving learning effects by means of teaching students in accordance with their aptitude, according to the actual majors, disciplines, basis of students and their potential in acceptance as well as the modernization teaching theory and based on the English teaching syllabus in classroom teaching. In the process of teaching, the teachers should adhere to the principle of students orientation, give full play to students' potential, mobilize students' subjective initiative, enable students at different levels to have their own interests in the process of learning, coordinate their development in terms of knowledge structure, language skills and psychology, learn and earn and finally facilitate the overall improvement of classroom teaching quality and students' quality. In the following, the author is going to explore necessity of Stratified English teaching.

In terms of education theory, Confucius, the ancient Chinese educator, proposed for the first time the ideas of teaching students in accordance with their aptitude and varying with each individual and practice this principle by himself. He advocated educating students with pertinence according to students' personality and speciality and proposing different requirements for students so as to make his disciples play up their strengths and avoid their weaknesses and learn something and promote their normal development. There is also a summary about the idea of teaching students in accordance with their aptitude in the ancient Chinese education monograph "Li Jing · Xue Ji", "There are often four disadvantages of a learner and an educator has to know about (that). In people's learning, they have the disadvantage of learning too much (but not to practice what they have learnt), the disadvantage of learning too little, the disadvantage of taking learning too easy and the disadvantage of stopping once encountered with a difficulty. These four kinds of people have different psychology. Only if an educator knows about their different psychology, can they remedy their disadvantages. As a teacher, it is his obligation to play up students' advantages and remedy their disadvantages. The Germany educator Diesterweg also pointed out, a teacher had to take full consideration of "the differences, deviations, features and characteristics that had appeared in the infancy period of a child" in the process of teaching and "could not and should not make everyone become the totally identical person and teach them the same knowledge". Teaching in accordance with the aptitude means "teaching students in accordance with their aptitude." Stratified teaching is helpful for teaching in accordance with the aptitude, which can not only repress students with good learning basis but will also not abandon those students with bad learning basis and will make each student acquire the optimal development in a learning environment that is most suitable for him/her.

In terms of linguistics theory, the US noted applied linguist Stephen D. Krashen put forward the concept of " $\mathrm{i}+1$ " in his input hypothesis. According to Krashen, the only approach for people to learn language is the comprehensive linguistic input and only if "input" is changed to "absorption", can the linguistic acquisition mechanism come into play and the linguistic level get possible improvement. That is to say, only effective comprehension can make acquisition possible, which can be expressed by the formula $i+1$, where $i$ stands for the current level of a language learner and 1 stands for the level slightly higher than language. If input of language knowledge is far higher than the current level of a language learner, namely, $i+2$, or is lower than the current level of a language learner, namely, $i+0$, then the language learner will lose enthusiasm and lose strong thirst for knowledge. In that way, in learning of a language learner will be unlikely to achieve the anticipated effect. Thus, input should neither far exceed the highest level attained by a language learner if he tries his utmost nor get too close to their current level so that they will not have any challenge at all (Krashen, 1982). This is exactly the quintessence and theoretical foundation of stratified 
teaching of college English.

So far as psychology theory is concerned, research by the Former Soviet Union psychologist Vygotsky indicated that, in the process of learning, all students had a distance or scope from the actual development level established in their independent resolving of problems to the possible or potential development level established by their resolving of problems under tutoring of teachers, namely, "the proximal development zone". Teaching should not only adapt to the current development level of students, but should also adapt to the "proximal development zone", so that students are able to walk in the front of development and finally step over the "proximal development zone" to achieve a new development level. The US psychologist B. S. Bloom also pointed out in his "Mastery Learning Theory" that, "The major reason why quite a lot of students are unable to achieve outstanding performance is not that their wisdom competence is deficient, but that they have not been able to obtain appropriate teaching conditions and rational assistance" and "if provided with appropriate learning conditions, a large majority of students will become quite similar in terms of learning capacity, learning speed and further learning motive." Thus, it can be seen that, playing of people's potential is restrained by multiple factors, such as, the society, family, teaching atmosphere, willpower, self-control and personality quality, etc. Teachers are supposed to propose different requirements for different levels of students in different subjects to the great extent according to the actual situation of students, provide students with different learning conditions, offer personal guidance, make the personal potential of students released as much as possible, let them learn successfully under the guidance of their own target and acquire development within their "proximal development zone".

Finally, in terms of economic theory, the British philosopher Jeremy Bentham took the lead in bringing the "utility concept" in economics to the social science field. Implementation of stratified English teaching can enable students to acquire the largest amount of knowledge within limited time. According to the "equal marginal principle" in economics, if a teacher puts equal teaching time to all students, there will be a large gap between the immediate utility of students. Therefore, teachers should not adopt a "unified" tactics in the process of teaching. Instead, they should distribute the teaching time in an effective way to different levels of students according to the standard of utility difference, so as to enable all students to acquire the maximum English knowledge amount in an immediate condition, such as, limited time and limited language basis, and ensure that all students make progress from a different starting point, which shows distinguished education.

\section{Discussion on Stratified Teaching Reform}

In the situation when students' English level is gradually improved and the credit hours of college English courses gradually diminished at the basic education stage, in addition to connecting English teaching in the senior middle schools, college English teaching should more reflect characteristics of higher education so as to satisfy demands of the country on high quality talents and on personal development of students. College English does not simply mean reading and writing courses and audio and visual courses. The stratified teaching model is to adopt students' good points and avoid their shortcomings on the pre-condition of acknowledging personal differences of students, set up the goal of "to all students, stratified teaching, different sorts of guidance and common development" and reflect the stratification idea in such aspects of teaching objects, teaching management, teaching process and assessment and evaluation, so as to enable each student to get the maximum development in interactive teaching practice of teaching and learning and finally facilitate substantial improvement of holistic teaching effect of college English.

The first step to carry out stratified teaching is to stratify the teaching objects. Implementation of stratified teaching is to make different teaching content and different teaching methods adapt to demands of different students. On the one hand, those students who have spare capacity to learn can obtain opportunities to improve their own English level and give full play to their potential. On the other hand, those students who have weak English basis can also have the opportunities to remedy their own disadvantages. According to the characteristics of agricultural and forestry universities and on the basis of generally classifying students into different classes according to different majors and subjects, the universities can further classify students into the three different sorts of teaching classes of honors class, regular class and arts and physical education class according to students' university entrance performance or final exam performance. In the meantime, the universities need to dynamically classify students into multiple levels within the teaching class. Prior to teaching, the teachers can get to know about students' interests, basic capacity, cognitive style, learning motive and personality, etc., by means of observation, questionnaire survey and test, and classify students into different levels according to their requirements for personal development to offer stratified English teaching. In the specific teaching process, if the method does not suit with teaching at this level, the universities can make adjustments at any time according to the development situation and students can be changed from a higher level to a lower level or from a lower level to a higher level. This helps to improve students' learning interests, stimulate their initiative and tap their potentials. 
After students' English levels are confirmed, teachers should adhere to the principle of classification in general management of teaching according to the general requirements of teaching materials and syllabus and the practical learning competence of students at different levels. In the first place, we should set up curriculum system and content system for stratified teaching according to cultivation goals and requirements of different students in different majors and considering the teaching requirements of college English, so as to show such characteristics of differences in disciplines, professional levels and students' individual differences, etc. For example, college English courses in high agricultural universities may show preference for the direction involving agriculture and may differ with differences of majors and disciplines. In the second place, on the basis of the principle of "application and utility", teachers may draw out different teaching guidance opinions in terms of English listening, speaking, reading, writing and translating of students at different levels, work out stratified teaching goals, including semester goal, weekly goal and class hour goal, such as, fundamental goal (for arts and physical education students), regular goal (for regular class students) and developmental goal (for honors class students). This may play a positioning, orientation and stimulating role in students' learning. Meanwhile, teachers may draw out teaching projects that fit in with different teaching goals, specify the basic teaching content and requirements of the teaching process, and work out corresponding teaching projects to reflect hierarchy according to the requirements of teaching syllabus so as to ensure the effects and quality of stratified teaching activities. In the third place, teachers who assume different levels of teaching tasks may organize multiple teaching teams that are equipped with a major principal and organize teachers' collective preparation of classes to get engaged in corresponding special subject research. At the time of summarizing experiences, teachers may cooperate in their job, communicate with each other about their situations, draw the strong points of others to offset their own weaknesses, improve themselves together and better improve curriculum setting and teaching management.

The stratification of the teaching process is the core of the entire reform. For the time being, English teaching is mainly embodied in class teaching, so the key to stratified teaching lies in the entire teaching process, which is also a part that can most likely enable teachers to play their initiative and creativity. First of all, teachers have to make a full preparation of themselves, adhere to the principle of taking students as the subjects of learning, select different teaching materials according to different levels of teaching goals and by referring to the knowledge of three different levels of students, employ different teaching methods and means, adjust teaching content, reflect stratification in terms of imparting, interrogating, interacting and question arrangement, and optimize classroom teaching. For example, in honors class teaching, teachers ought to use more English to teach their class, adopt the method of less lecturing by teachers and more practicing by students and design enriched practical classroom activities. At the same time, teachers may add some pertinent and applicable extracurriculum knowledge and provide the opportunity for students to make use of independent learning system on the college English network. It is necessary for teachers to do their best to create conditions for students to learn by themselves, improve students' sense of language and interpersonal competence and pay attention to cultivate students' independence and capacity of research learning. In regular class teaching, teachers ought to put much effort to teach and to let students to practice and mobilize students' personality potential. They may choose the pattern of bilingual teaching both in Chinese and in English, finish transition from strange words, short phrases sentences and gradually to semantic meaning and discourse, finish the process of gradually improving students' competence of listening, speaking, reading and writing and concentrate on improvement of language usage capacity on the basis of English basic knowledge and impartation and cultivation of practical skills. In teaching of arts and physical education classes, teachers ought to focus on training of practical application skills, put down the starting points of students, give as many as lectures and let students practice as much as they can and enable students to try to grasp necessary knowledge and skills. In the process of teaching, teachers should attempt to create opportunities for students at each level to take part in classroom teaching, design flexible teaching activities, mobilize students' initiative in learning, practically improve the actual effects of classroom teaching and enable each student to get successful experience.

Finally, stratification should be implemented in assessment and evaluation. The purpose of language test is, on the one hand, to evaluate the language competence of students by a scientific, objective, accurate and justified test means, and, on the other hand, to measure the teaching effect and to serve for further improvement of teaching quality. Thus, different evaluation standards should be formulated for different levels of students. In the teaching practice, teachers have to make a formative assessment in accordance with students' personal differences, know about the situation of students' achievement of the stratification goal in time and make an accurate judgment on the effects of teachers who implement stratification. In the unit test, mid-term examination and final examination, teachers should draw out different examination papers and set different aims according to different teaching. The examination form can also reflect differences of students. For example, a test with combination of oral test and written test can be conducted for students in the honors class. At the time when teachers ensure that students get a reasonable performance, they can make accurate evaluation on different levels of students. They should set up a 
dynamic and comprehensive assessment and evaluation system that is centered with quality assessment, measures teaching quality and students' learning ability in a scientific way.

\section{Dos and Don'ts in Implementation of Stratified Teaching}

Stratified teaching may cause certain change in students' psychology. Hence, the work of psychological counseling on students seems especially important. Teachers should make student aware clearly that the purpose of stratification is not to make distinction between stand and fall, but to teach them in accordance with their aptitude and teaching at different levels is to achieve better teaching effects. Likewise, by means of adjustment and change of different levels, introduction of effective competition mechanism into English learning helps to stimulate students' interests in learning English and to enable different students to get sufficient improvement on the original basis. The lecturers ought to pay attention to give much observation and get more understanding, communicate frequently with students and give them much encouragement. In the meantime, so far as the current situation of teachers is concerned, there is still a great gap between the status quo of the teachers' team and the requirements of stratified teaching, so it is necessary to strengthen construction of teachers' team. Teachers ought to further strengthen management and research of implementation of stratified teaching, go into an in-depth analysis of the plan and implementation project of stratified teaching, carry out the measures of stratified teaching, implement the teaching plan, ensure the teaching effect and realize the immediate teaching goal. On the basis of defining the purpose and significance of stratified teaching, teachers ought to further improve stratified teaching by means of continuous practical exploration. At the same time, teachers should treat different levels of students equally without discrimination, put an end to any despicable psychology and continue to improve the teaching level and teaching effect.

In addition, the universities should take an initiative in supporting the stratified teaching mode, offer assistance in terms of policy and funds and require the administrative departments and teachers to positively cooperate in relevant specific policies or methods. The students ought to be organized into new teaching classes after stratified teaching. The teachers and the students should mutually communicate and discuss about the daily teaching discipline management of students and class advisers' arrangement in division of work. Besides, the student personnel administration department should also need to take an initiative in cooperation by means of giving feedback in time about students' examination or CET performance and, meanwhile, improve relevant curriculum setting and arrangement as well as assessment and evaluation.

\section{Conclusion}

The starting point of stratified teaching is to start out from students' reality and concentrate on and show respect for each student. Stratified teaching is a challenge to the traditional education modes and corresponds with the principle of teaching students in accordance with their aptitude and teaching step by step. On the basis of paying attention to students' differences in learning competence, stratified teaching respects the personalized development of students, reflect the idea of human orientation and is a sort of matter-of-fact teaching form. This teaching process is not only helpful for students to have enough learning and development freedom and space, but is also helpful to strengthen teachers' leading role. This helps to really realize the dependence-based and task-based stratified teaching mode according to different people, at different time and in different places, establishing language on the basis of teaching of a certain subject or a certain subject content by means of constructing rationalized teaching syllabus, diversified teaching methods, modernized teaching means and perfect evaluation system, facilitate development of students' language competence at the time of enhancing students' subject knowledge level and cognitive competence, and furthermore reduce the tendency of separation of language education from subject knowledge that is artificially caused. So far as Sichuan Agricultural University is concerned, the reform of college English walks in the front of all universities in Sichuan Province. According to the actual situation of students, the university takes the lead in compressing teaching cycles and class hours and carries out the system of selecting to learn a course free of charge to avoid waste of teaching resources. However, this also directly causes basic disconnection of students' English learning after CET-4 and their English-learning enthusiasm is reduced. In the meantime, the importance, rationality and applicability of the existing college English courses are open for further discussion. We should start out from students' demands and the characteristics of the university per se, take a positive attitude in establishing stratified teaching mode that is established for subject content and knowledge according to "Teaching Requirements for College English Curriculum", open and set up corresponding courses, improve the evaluation system, set up a three-dimensional teaching system, let students get a mastery of subject content, broaden their field of vision and make them better fit in with the internationalization requirements. With enrichment and improvement of stratified teaching in theoretical research and practical teaching, it will provide a wider platform for higher agricultural universities to realize an ideal English teaching goal and offer an actual and effective demonstration to enhance teaching quality to a large extent. 


\section{References}

Chen, Linxia. (2005). Importance of College English Level-based Teaching. Heilongjiang Researches on Higher Education, 1.

Department of Higher Education, Ministry of Education. (2007). Teaching Syllabus of College English. Beijing: Higher Education Press.

$\mathrm{Hu}$, Zhuanglin. (2002). Course in Linguistics. Beijing: Peking University Press.

Krashen, S. D. (1982). Principles and Practice in Second Language Acquisition. New York: Pergamon Press Ltd.

Lin, Mei. (2008). Theoretical Summary of Stratified English Teaching. Journal of Chongqing University of Science and Technology, 3.

Liu, Runqing. (1999). On English Language Teaching. Beijing: Foreign Language Teaching and Research Press.

Shu, Dingfang. (2006). On the Teaching Mode in Foreign Language Classes. Foreign Language World, 04.

Wang, Shouren. (2011). Status Survey on College English Teaching in Chinese Universities and Direction of Reform and Development of College English Teaching. Foreign Languages in China, 05.

Zhao, Liang. (2010). Discussion on Stratified Teaching in College English. Education and Vocation, 08.

Zhou, Yonngmo. (2011). College English Teaching in agricultural and forestry universities of China:current situation analysis and countermeasures. Journal of Shanghai Ocean University, 02.

\section{Author}

Liu Yang was born in Sichuan, China in 1980. She received her M.A. Degree in linguistics from Sichuan Normal University, China in 2005.

She is currently a lecturer in the College of Literature and Law, Sichuan Agricultural University, Sichuan, China. Her research interests include applied linguistics and cross-cultural communication. 